\title{
The efficacy of dermofat grafts from the groin for correction of acquired facial deformities
}

\author{
Min Hyub Choi ${ }^{1}$, \\ Wei Jie $\mathrm{He}^{2}$, \\ Kyung Min Son ${ }^{1}$, \\ Woo Young Choi ${ }^{1}$, \\ Ji Seon Cheon ${ }^{1}$ \\ ${ }^{1}$ Department of Plastic and \\ Reconstructive Surgery, Chosun \\ University College of Medicine, \\ Gwangju; ${ }^{2}$ Department of Plastic and \\ Reconstructive Surgery, Chosun \\ University Graduate School of \\ Medicine, Gwangju, Korea
}

\begin{abstract}
Background: Posttraumatic acquired facial deformities require surgical treatment, with options including scar revision, fat grafts, implant insertion, and flap coverage. However, each technique has specific advantages and disadvantages.

Methods: From 2016 to 2018, 13 patients (eight with scar contracture and five with a depressed scar) were treated using dermofat grafts from the groin. The harvested dermofat was then inserted into the undermined dead space after the contracture was released, and a bolster suture was done for fixation considering the patient's contour and asymmetry. A modified version of the Vancouver Scar Scale and satisfaction survey were used to compare deformity improvements before and after surgery.

Results: In most cases, effective volume correction and an aesthetically satisfactory contour were maintained well after dermofat grafting, without any major complications. In some cases, however, lipolysis proceeded rapidly when inflammation and infection were not completely eliminated. A significant difference was found in the modified Vancouver Scar Scale before and after surgery, with a $p$-value of 0.001 . The average score on the satisfaction survey was 17.07 out of 20 points.

Conclusion: A dermofat graft with the groin as the donor site can be considered as an effective surgical option that is the simplest and most cost-effective method for the treatment of acquired facial deformities with scar contracture.
\end{abstract}

Keywords: Autografts / Face / Reconstructive surgical procedures / Treatment outcome

\section{INTRODUCTION}

Soft tissue deformities can occur as a result of various causes, including trauma, burns, infections, and skin diseases. Among these causes, facial trauma is noteworthy as a mechanism because it causes injury of the facial soft tissue accompanied by facial bone fracture and may leave behind an acquired facial deformity, such as contour depression or scar contracture [1].

\section{Correspondence: Kyung Min Son}

Department of Plastic and Reconstructive Surgery, Chosun University College of

Medicine, 365 Pilmun-daero, Dong-gu, Gwangju 61453, Korea

E-mail: 8love17@hanmail.net

This work was supported by the Chosun University research fund.

Received January 16, 2020 / Revised April 13, 2020 / Accepted April 16, 2020
Small and large acquired facial deformities require secondary facial reconstruction through a skin graft, fat graft, flap coverage, or implant insertion. The goals of acquired facial deformity reconstruction are to restore a normal facial contour and to eliminate the asymmetry of the deformity site. To achieve these goals, numerous distinct surgical techniques can be used and multiple operations may be required in some cases. However, facial reconstruction should be performed with appropriate consideration of color, texture, and flexibility, as these factors influence quality of life. Thus, facial reconstruction is challenging for both patients and clinicians [2]. Furthermore, patients who have already undergone one or more operations due to trauma may feel that repeated surgery is burdensome for vari- 
ous reasons.

Therefore, the purpose of our study was to evaluate the degree to which dermofat grafts, a technique that is most often used for aesthetic purposes, could be an effective treatment for acquired facial deformities caused by facial trauma. By doing so, we aimed to reduce the surgical and economic burden of these procedures.

\section{METHODS}

\section{Patients}

Among all patients who received surgical treatment of the head and neck due to trauma from August 2015 to January 2019, 13 patients (eight with scar contracture, five with a contour depression) were treated with a dermofat graft using the groin as the donor site to correct an acquired facial deformity. Patients' demographic information was collected through their medical records. The study was approved by the Institutional Review Board of Chosun University Hospital (IRB No. 2019-09-003-002).

\section{Surgical technique}

After providing sufficient local anesthesia at the acquired deformity site using a lidocaine injection, the existing scar was excised or a minimum incision was performed through the hair line or wrinkle line. Fibrotic tissue and the tethering scar were removed from areas of scar contracture and depression, and undermining dissection was performed at the deformity site. At this point, with appropriate consideration of patients' facial symmetry and contour, the volume deficiency at the deformity site should be evaluated to determine the extent of reconstruc- tion needed.

Once sufficient dead space was secured after completing the dissection of the deformity site, an incision was made at the groin crease and a dermofat graft was harvested with the groin as the donor site. Approximately $120 \%$ of the desired amount of the dermofat graft was harvested, accounting for predicted tissue resorption [3]. While harvesting the dermofat graft, the use of electrocautery devices, such as Bovie or bipolar units, was limited to the minimum extent possible considering the possibility of thermal damage [4]. Based on our surgical experience, it was quite possible to harvest up to $8 \times 6 \mathrm{~cm}$. The epidermal layer and hair follicles of the harvested dermofat were then removed. The well-designed dermofat graft was inserted as appropriate given the dead space at the deformity site, and then the incision site was closed. Finally, considering the patient's contour and asymmetry, the procedure was finished with a fixation suture as a bolster (Fig. 1).

\section{Postoperative care}

When this procedure is performed, admission to the hospital after surgery is not usually necessary, and the patient can receive postoperative care at an outpatient clinic. Oral analgesics and prophylactic antibiotics were prescribed for 5 days, and followup observations were made. A compressive wet gauze dressing was placed on the recipient site and a foam dressing was placed on the donor site. Although the precise timing depended on the site, stitch-out was performed according to the suture location and condition at 4-5 days, 5-7 days, and 7-10 days after surgery for bolster sutures, the incision at the recipient site, and the incision at the donor site in the groin, respectively.
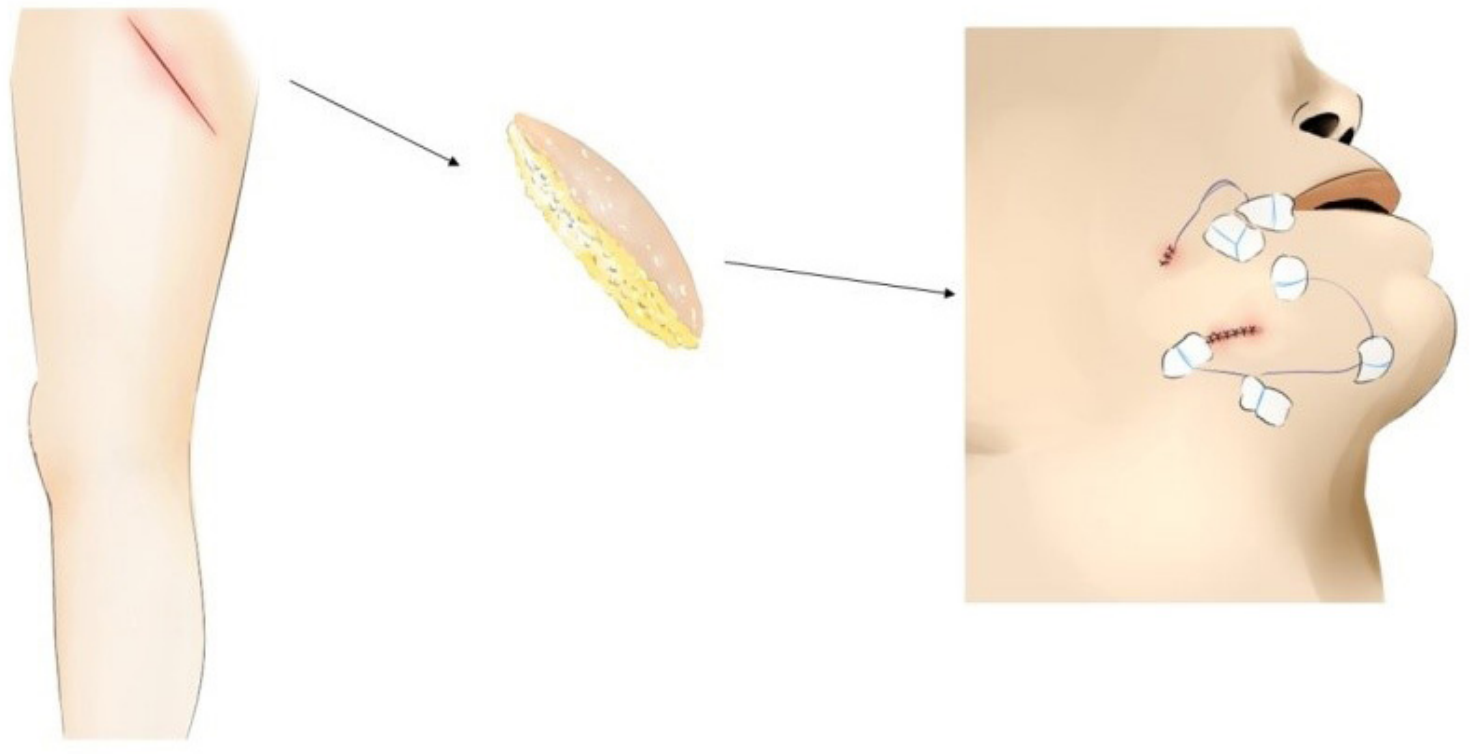

Fig. 1. Schema of a dermofat graft. 


\section{Deformity assessment}

To evaluate the postoperative improvement of the deformities, a modified version of the Vancouver Scar Scale (mVSS) focusing on the size of the depressed area was used (Table 1). A trained assistant (MHC) evaluated patients' preoperative photographs and postoperative photographs taken at least 4 months after treatment with medical records. The difference in mVSS scores before and after surgery was analyzed using the non-parametric Wilcoxon signed-rank test. All statistical analyses were performed using SPSS version 23.0 (IBM Corp., Armonk, NY, USA). Statistical significance was defined as a $p$-value less than 0.05 .

\section{Postoperative satisfaction assessment}

Patients' aesthetic satisfaction was verbally evaluated at least 4 months after surgery through questions that dealt with patients' evaluation of the deformity site and donor site. The following four questions were asked, with scores closer to 5 points indi-

Table 1. Modified Vancouver Scar Scale

\begin{tabular}{|c|c|}
\hline Scar characteristics & Score \\
\hline \multicolumn{2}{|l|}{ Vascularity } \\
\hline Normal & 0 \\
\hline Pink & 1 \\
\hline Red & 2 \\
\hline Purple & 3 \\
\hline \multicolumn{2}{|l|}{ Pigmentation } \\
\hline Normal & 0 \\
\hline Hypopigmentation & 1 \\
\hline Hyperpigmentation & 2 \\
\hline \multicolumn{2}{|l|}{ Pliability } \\
\hline Normal & 0 \\
\hline Supple & 1 \\
\hline Yielding & 2 \\
\hline Firm & 3 \\
\hline Ropes & 4 \\
\hline Contracture & 5 \\
\hline \multicolumn{2}{|l|}{ Height (mm) } \\
\hline Flat & 0 \\
\hline$<2$ & 1 \\
\hline $2-5$ & 2 \\
\hline$>5$ & 3 \\
\hline \multicolumn{2}{|l|}{ Depression $\left(\mathrm{cm}^{2}\right)$} \\
\hline Flat & 0 \\
\hline$<4$ & 1 \\
\hline $4-9$ & 2 \\
\hline$>9$ & 3 \\
\hline Total score & 16 \\
\hline
\end{tabular}

cating higher satisfaction: (Q1) Are you satisfied with the postoperative scar at the deformity site? (1-5); (Q2) Are you satisfied with the postoperative contour of the deformity site? (1-5); (Q3) Are you satisfied with the postoperative scar at the donor site? (1-5); and (Q4) Are you satisfied with the overall results of surgery? (1-5).

\section{RESULTS}

A total of 13 patients (seven males and six females) received dermofat grafts. Their mean age was 55.69 years old. Although five patients had a contour depression and eight had scar contracture, most of them showed a mixture of the two deformity types. The deformity site was the upper face in five patients, the mid-face in seven patients, and the lower face in one patient. The maximum deformity size was $8 \times 6 \mathrm{~cm}^{2}$, the minimum size was $4 \times 2 \mathrm{~cm}^{2}$, and the average area of the deformity was 19.77 $\mathrm{cm}^{2}$. Twelve of the 13 patients underwent surgery under local anesthesia without sedation, while one patient underwent surgery under general anesthesia due the additional need to correct enophthalmos. On average, surgery took 80 minutes, and the mean follow-up period was 7.3 months

Complications occurred at the recipient site in three patients; one patient showed hair growth, and two patients rapidly developed lipolysis due to an obvious infection. For the patients who developed lipolysis, repeated surgery and an additional treatment such as a fat graft were performed. An aesthetically satisfactory contour was achieved in most cases. All patients recovered without major complications at the donor site, except for one patient with a mild hypertrophic scar (Figs. 2-4).

The patients' average preoperative mVSS score was 9.15, and the average postoperative mVSS score was 4 (Table 2). The change in mVSS scores before and after surgery was greater in patients with scar contracture (patient Nos. 5-13) than in patients with a contour depression alone (patient Nos. 1-4). In addition, the preoperative mVSS and postoperative mVSS scores showed a significant difference, with a $p$-value of 0.001 using the Wilcoxon signed-rank test (Fig. 5). The average score was 17.07 points (out of 20) in the survey on postoperative satisfaction, and the average score for each question was over 4 points. These results indicate that the patients were generally satisfied (Table 3).

\section{DISCUSSION}

Implantation of a dermofat graft was first reported in Germany in 1913. A dermofat graft is defined as one that includes the full-thickness dermis and a subcutaneous layer around the 

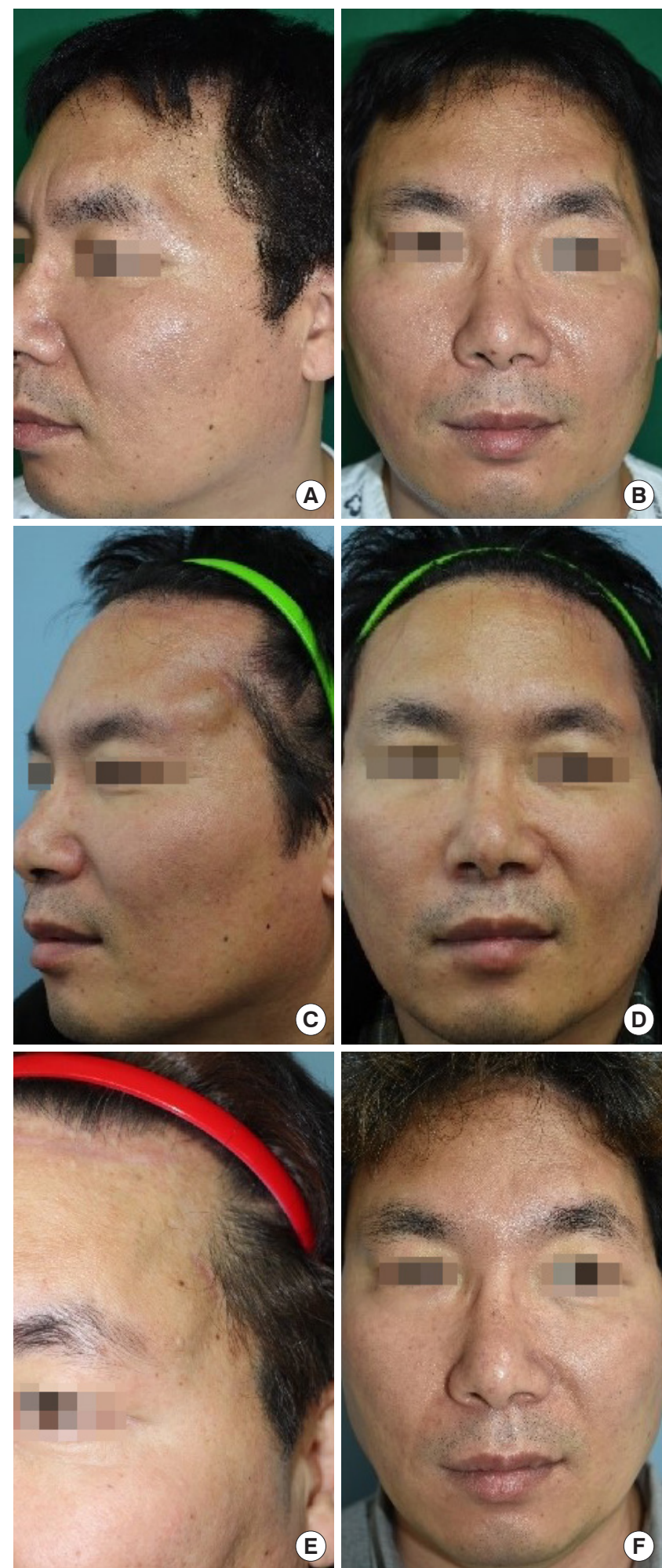

Fig. 2. Patient No. 2. A 48-year-old man with depression contour of his left forehead. After a motorcycle accident, the patient had received open reduction and internal fixation for a left tripod fracture and blowout fracture, and underwent cranioplasty performed by a neurosurgeon using a mesh-type metallic plate due to a fracture compound comminuted depression in the temporoparietal area. (A, B) Preoperative photographs. (C, D) Two-week postoperative photographs. (E, F) Five-month postoperative photographs.
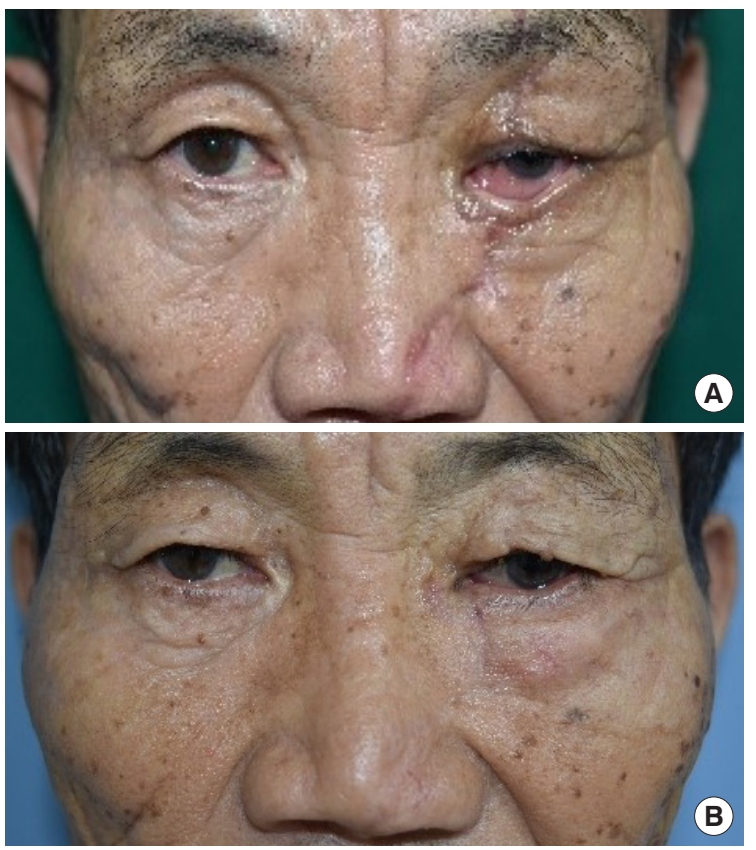

Fig. 3. Patient No. 6. A 64-year-old man with severe ectropion caused by lower eyelid scar contracture. He had received emergency exploratory surgery, debridement, and primary closure due to severe facial lacerations from the left upper eyelid to the upper lip caused by an accident while working with an electric saw. Two months after surgery, due to the severity of the scar and contracture, severe ectropion occurred in the left lower eyelid. (A) Preoperative photograph. (B) Seven-month postoperative photograph.

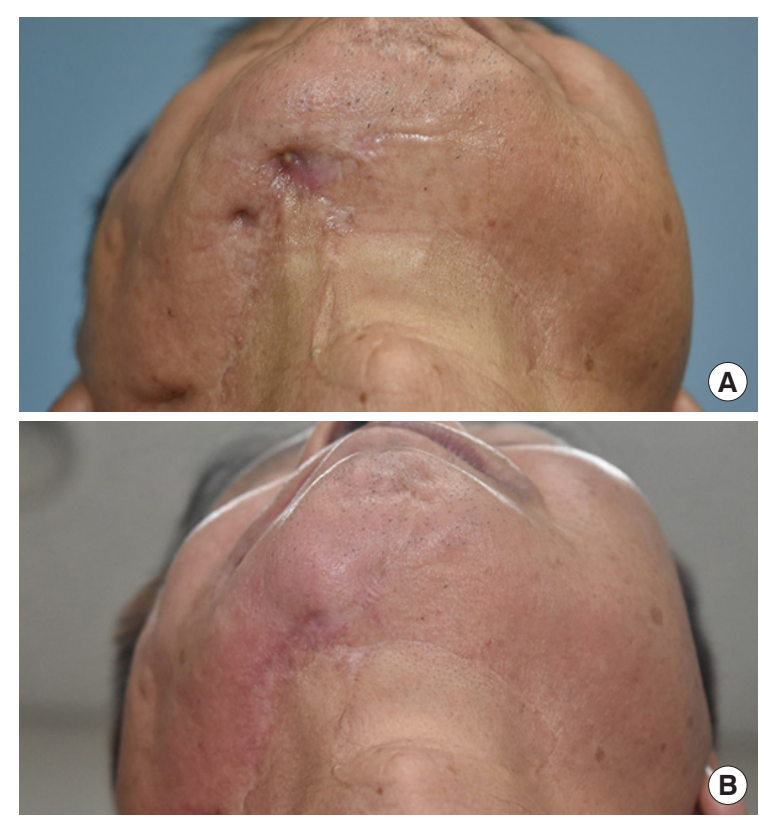

Fig. 4. Patient No. 7. A 64-year-old man presented with a severe scar contracture in the jaw area. The patient had undergone emergency open reduction and internal fixation due to a panfacial open fracture, including a right tripod fracture, blowout fracture, and severe right mandibular body fracture, due to the explosion of a fire extinguisher. (A) Preoperative photograph. (B) Four-month postoperative photograph. 
Table 2. Characteristics of the patients

\begin{tabular}{|c|c|c|c|c|c|c|c|c|c|c|c|c|}
\hline Patient No. & Age $(y r) / s e x$ & $\begin{array}{l}\text { Deformity } \\
\text { type }\end{array}$ & $\begin{array}{l}\text { Deformity } \\
\text { site }\end{array}$ & $\begin{array}{l}\text { Deformity } \\
\text { size }\left(\mathrm{cm}^{2}\right)\end{array}$ & $\begin{array}{c}\text { Anesthesia } \\
\text { type }\end{array}$ & $\begin{array}{l}\text { Operating } \\
\text { time (min) }\end{array}$ & $\begin{array}{l}\text { Follow-up } \\
\text { period (mo) }\end{array}$ & $\begin{array}{l}\text { Recipient site } \\
\text { complications c }\end{array}$ & $\begin{array}{l}\text { Donor site } \\
\text { complications }\end{array}$ & $\begin{array}{c}\text { Preoperative } \\
\text { mVSS }\end{array}$ & $\begin{array}{l}\text { Postoperative } \\
\text { mVSS }\end{array}$ & $\begin{array}{c}\text { Change in } \\
\text { mVSS }\end{array}$ \\
\hline 1 & $21 / F$ & $\begin{array}{l}\text { Contour } \\
\text { depression }\end{array}$ & $\begin{array}{l}\text { Right temporal } \\
\text { area } \\
\text { Forehead }\end{array}$ & $7 \times 6$ & Local & 150 & 28 & None & None & 5 & 1 & 4 \\
\hline 2 & $48 / \mathrm{M}$ & $\begin{array}{l}\text { Contour } \\
\text { depression }\end{array}$ & $\begin{array}{l}\text { Left forehead } \\
\text { Temporal area }\end{array}$ & $8 \times 6$ & Local & 140 & 13 & None & None & 5 & 1 & 4 \\
\hline 3 & $66 / F$ & $\begin{array}{l}\text { Contour } \\
\text { depression }\end{array}$ & Right forehead & $5 \times 4$ & General & 150 & 4 & $\begin{array}{l}\text { Infection, } \\
\text { lipolysis }\end{array}$ & None & 5 & 2 & 3 \\
\hline 4 & $53 / \mathrm{M}$ & $\begin{array}{l}\text { Contour } \\
\text { depression }\end{array}$ & $\begin{array}{l}\text { Left forehead } \\
\text { Temporal area }\end{array}$ & $7 \times 6$ & Local & 60 & 6 & None & None & 6 & 2 & 4 \\
\hline 5 & $37 / \mathrm{M}$ & $\begin{array}{l}\text { Scar contrac- } \\
\text { ture } \\
\text { Contour de- } \\
\text { pression }\end{array}$ & $\begin{array}{c}\text { Forehead right } \\
\text { eyebrow }\end{array}$ & $5 \times 2$ & Local & 60 & 6 & Hair growth & None & 10 & 2 & 8 \\
\hline 6 & $64 / \mathrm{M}$ & $\begin{array}{l}\text { Scar } \\
\text { contracture } \\
\text { Ectropion }\end{array}$ & $\begin{array}{l}\text { Left lower } \\
\text { eyelid }\end{array}$ & $4 \times 2$ & Local & 60 & 7 & None & None & 12 & 5 & 7 \\
\hline 7 & $64 / \mathrm{M}$ & $\begin{array}{l}\text { Scar } \\
\text { contracture }\end{array}$ & Chin & $6 \times 5$ & Local & 60 & 4 & None & None & 10 & 4 & 6 \\
\hline 8 & $48 / F$ & $\begin{array}{l}\text { Scar } \\
\text { contracture } \\
\text { Ectropion }\end{array}$ & $\begin{array}{l}\text { Right lower } \\
\text { eyelid }\end{array}$ & $4 \times 2$ & Local & 60 & 4 & $\begin{array}{l}\text { Infection, } \\
\text { lipolysis }\end{array}$ & None & 12 & 8 & 4 \\
\hline 9 & $71 / \mathrm{M}$ & $\begin{array}{l}\text { Scar } \\
\text { contracture } \\
\text { Ectropion }\end{array}$ & $\begin{array}{l}\text { Right lower } \\
\text { eyelid }\end{array}$ & $4 \times 2$ & Local & 60 & 4 & None & $\begin{array}{l}\text { Hypertrophic } \\
\text { scar }\end{array}$ & 13 & 7 & 6 \\
\hline 10 & $78 / \mathrm{M}$ & Ectropion & $\begin{array}{l}\text { Left lower } \\
\text { eyelid }\end{array}$ & $4 \times 2$ & Local & 60 & 4 & None & None & 13 & 6 & 7 \\
\hline 11 & $66 / F$ & $\begin{array}{l}\text { Scar } \\
\text { contracture } \\
\text { Ectropion }\end{array}$ & $\begin{array}{l}\text { Right lower } \\
\text { eyelid }\end{array}$ & $4 \times 2$ & Local & 90 & 4 & None & None & 12 & 6 & 6 \\
\hline 12 & $43 / F$ & $\begin{array}{l}\text { Scar } \\
\text { contracture }\end{array}$ & Forehead & $5 \times 3$ & Local & 90 & 6 & None & None & 8 & 4 & 4 \\
\hline 13 & $65 / F$ & $\begin{array}{l}\text { Scar } \\
\text { contracture }\end{array}$ & Left cheek & $5 \times 2$ & Local & 60 & 5 & None & None & 8 & 4 & 4 \\
\hline Mean $\pm S D$ & $55.69 \pm 15.83$ & - & - & $19.77 \pm 15.27$ & - & $84.62 \pm 37.17$ & $7.31 \pm 6.69$ & - & - & $9.15 \pm 3.16$ & $4.00 \pm 2.31$ & $5.15 \pm 1.57$ \\
\hline
\end{tabular}

mVSS, modified Vancouver Scar Scale, F, female; M, male.
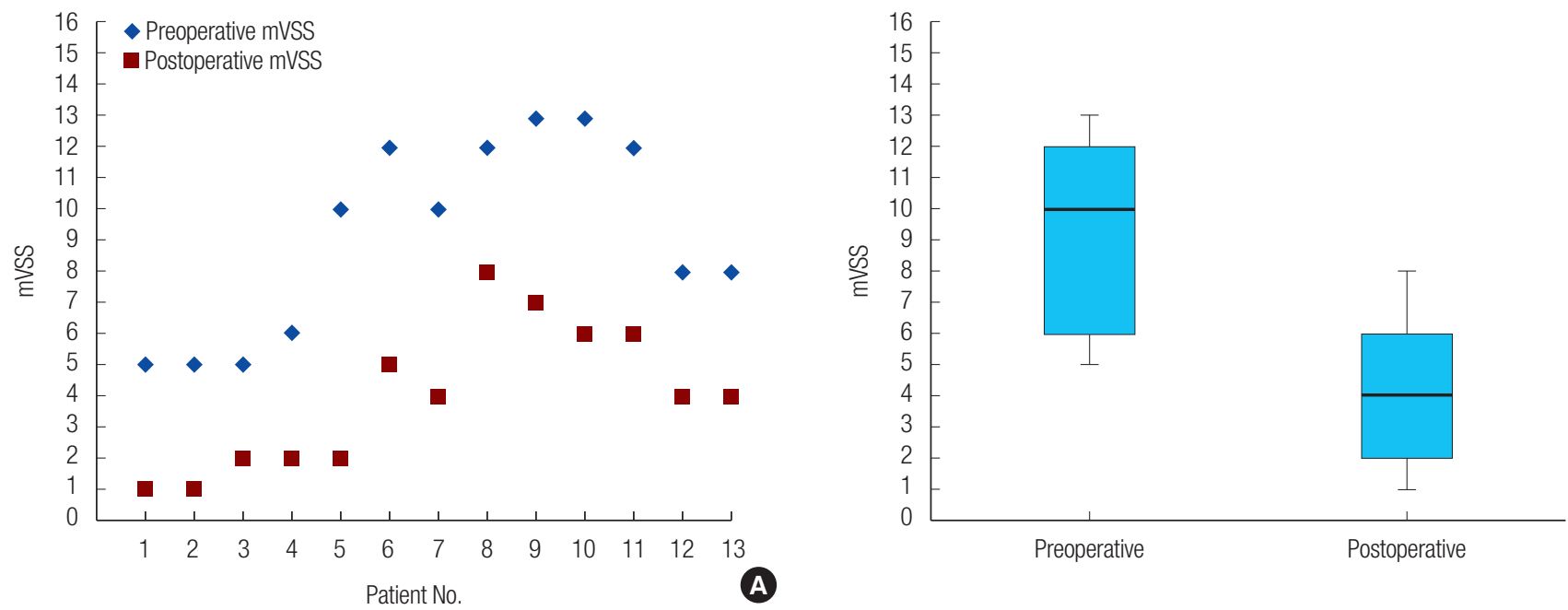

Fig. 5. (A, B) Preoperative and postoperative modified Vancouver Scar Scale (mVSS) changes ( $p=0.001$ from the Wilcoxon signed-rank test).

graft. Most commonly, the ideal donor site is the groin, the lateral area of the gluteal line or the abdomen; however, various sites can be harvested considering the size and texture needed for the recipient site, as the thickness of the skin and fat layer 
Table 3. Postoperative aesthetic satisfaction scores

\begin{tabular}{|c|c|c|c|c|c|}
\hline \multirow{2}{*}{ Patient No. } & \multicolumn{4}{|c|}{ Satisfaction score } & \multirow{2}{*}{ Total } \\
\hline & Q1 & Q2 & Q3 & Q4 & \\
\hline 1 & 5 & 5 & 4 & 5 & 19 \\
\hline 2 & 5 & 5 & 5 & 5 & 20 \\
\hline 3 & 3 & 3 & 4 & 3 & 13 \\
\hline 4 & 5 & 5 & 4 & 5 & 19 \\
\hline 5 & 5 & 5 & 5 & 5 & 20 \\
\hline 6 & 3 & 3 & 5 & 2 & 13 \\
\hline 7 & 4 & 4 & 3 & 4 & 15 \\
\hline 8 & 5 & 5 & 4 & 5 & 19 \\
\hline 9 & 4 & 4 & 5 & 4 & 17 \\
\hline 10 & 4 & 4 & 4 & 4 & 16 \\
\hline 11 & 4 & 5 & 5 & 4 & 18 \\
\hline 12 & 4 & 4 & 4 & 4 & 16 \\
\hline 13 & 5 & 4 & 4 & 4 & 17 \\
\hline Mean \pm SD & $4.31 \pm 0.75$ & $4.31 \pm 0.75$ & $4.31 \pm 0.63$ & $4.15 \pm 0.89$ & $17.07 \pm 2.39$ \\
\hline
\end{tabular}

Higher scores (5 points) indicate greater satisfaction. Q1: Are you satisfied with the postoperative scar at the deformity site? Q2: Are you satisfied with the postoperative contour of the deformity site? Q3: Are you satisfied with the postoperative scar at the donor site? Q4: Are you satisfied with the overall results of surgery?

varies by site $[5,6]$. Recently, the use of dermofat grafts for aesthetic purposes has been described in several reports [6-8], and they can be used in a variety of cases, including congenital deformities and those caused by neoplasms, infection, aging, or trauma [5].

Dermofat grafts are often compared to other surgical methods that can be used for facial deformities. In dermofat grafts, excised fat that is not been centrifuged is grafted. Although different results have been reported in various studies, the volume loss of dermofat has been reported to be from $1 \%-2 \%$ to $10 \%-$ $20 \%$, whereas $45 \%$ of the weight of aspirated fat is lost in 1 year [3]. Furthermore, as the dermis layer increases the graft survival rate by enhancing vascularization in the fat layer, there is no need for extensive overcorrection [6]. And its dermis layer helps to be placed dermofat graft in the desired location [8]. Compared to fat grafts, the donor site has fewer postoperative complications related to donor site hematoma, pain, burns around the liposuction site $[9,10]$.

Dermofat grafts differ in dermis thickness and fibroblast number according to harvest areas, so it is important to select harvest areas according to purpose. Sacral area is used for rhinoplasty because it has the thick dermis, compact fat layer and more fibroblasts. This difference makes the dermofat grafts in the sacral area more durable than other areas [11]. On the other hand, groin has dermis of the thinnest unlike other harvesting area for aesthetic surgery, the groin area has sufficient skin laxity. Therefore, an adequately large graft can be harvested with inconspicuous scar, and the thin dermis in this area makes it easy to create a relatively natural shape to correct the contour. Conventionally, dermofat grafts with groin as donor site were mainly used in aesthetic surgery $[7,8,12]$. The main purpose is contour augmentation. However, because the posttraumatic facial acquired deformity is relatively wide area and accompanied by scar contracture, approaching the surgical site using these scars can also lead to scar improvement, making treatment more efficient.

Compared to coverage with a prefabricated flap, local flap, or free flap [12-14], which are other options for secondary facial reconstruction, dermofat grafts also have the advantages of a short operating time and hospital stay, as well as straightforward postoperative management. In this study, none of the patients who underwent dermofat surgery had limited mobility or required complex management after surgery (such as flap monitoring); therefore, they all could be discharged immediately after surgery. In dermofat grafts, the donor site has less morbidity [15-17], such as a large scar and tightness after surgery, than occurs with flap coverage. Furthermore, the overall medical expenses including treatment are low.

However, the disadvantages of dermofat grafts include a certain level of instability in their long-term prognosis due to fat resorption, a relatively high vulnerability to infection $[3,4,6]$, and the possibility of only harvesting a limited amount, despite the variety of possible harvest sites. Additionally, a linear scar is left postoperatively at the donor site, and an incision needs to be made for dermofat grafts. Also, due to the lack of sufficient flexibility, dermofat grafts are difficult in highly mobile sites, such as the lips. Furthermore, hair growth from follicle and cyst formation have been reported in some cases [6].

The limitations of this study include its small sample size, short follow-up period, and the difficulties involved in making an objective comparison of contour and symmetry improvements. Therefore, a longer follow-up period is required, with more subjects, and methods for making objective before-andafter comparisons (e.g., through computed tomography or magnetic resonance imaging findings and three-dimensional calculations) are also needed.

In conclusion, dermofat grafts with the groin as the donor site reduced the burden of reoperation, length of hospital stay, and the cost of surgery, and were effective for improving deformities, resulting in high patient satisfaction. Therefore, dermofat grafts with the groin as the donor site can be considered as an effective surgical option that is the simplest and most cost-effective method for the treatment of acquired facial deformities with scar contracture. 


\section{NOTES}

\section{Conflict of interest}

No potential conflict of interest relevant to this article was reported.

\section{Ethical approval}

The study was approved by the Institutional Review Board of Chosun University Hospital (IRB No. 2019-09-003-002) and performed in accordance with the principles of the Declaration of Helsinki. Written informed consents were obtained.

\section{Patient consent}

The patients provided written informed consent for the publication and the use of their images.

\section{ORCID}

Min Hyub Choi https://orcid.org/0000-0002-6844-0526

Wei Jie He https://orcid.org/0000-0002-9876-9103

Kyung Min Son https://orcid.org/0000-0001-5825-0270

Ji Seon Cheon https://orcid.org/0000-0001-8555-5088

Woo Young Choi https://orcid.org/0000-0001-8849-1569

\section{REFERENCES}

1. Song B, Zhao J, Guo S, Yi C, Liu C, He L, et al. Repair of facial scars by the free expanded deltopectoral flap. Plast Reconstr Surg 2013;131:200e-208e.

2. Pomahac B, Bueno EM, Sisk GC, Pribaz JJ. Current principles of facial allotransplantation: the Brigham and Women's Hospital Experience. Plast Reconstr Surg 2013;131:1069-76.

3. Fagrell D, Enestrom S, Berggren A, Kniola B. Fat cylinder transplantation: an experimental comparative study of three different kinds of fat transplants. Plast Reconstr Surg 1996;98:90-6.

4. Honeybrook A, Athavale SM, Rangarajan SV, Rohde SL, Netterville JL. Free dermal fat graft reconstruction of the head and neck: an alternate reconstructive option. Am J Otolaryngol 2017; 38:291-6
5. Chiu DWT, Bradford WE. Repair and grafting of dermis, fat and fascia. In: McCarthy JC, editor. Plastic surgery. Philadelphia: WB Saunders; 1990. p. 509-26.

6. Little JW. Applications of the classic dermal fat graft in primary and secondary facial rejuvenation. Plast Reconstr Surg 2002; 109:788-804.

7. Yang SJ, Kim BS, Kim JH. Secondary augmentation rhinoplasty with dermofat graft. J Korean Soc Plast Reconstr Surg 1998; 25:152-60.

8. Hwang K, Han JY, Kim DJ. Dermofat graft in deep nasolabial fold and facial rhytidectomy. Aesthetic Plast Surg 2003;27:2547.

9. Liu SS, Strodtbeck WM, Richman JM, Wu CL. A comparison of regional versus general anesthesia for ambulatory anesthesia: a meta-analysis of randomized controlled trials. Anesth Analg 2005;101:1634-42.

10. Matarasso A, Levine SM. Evidence-based medicine: liposuction. Plast Reconstr Surg 2013;132:1697-705.

11. Guo L, Pribaz JJ. Clinical flap prefabrication. Plast Reconstr Surg 2009;124(6 Suppl):e340-50.

12. Hwang K, Kim DJ, Lee IJ. An anatomic comparison of the skin of five donor sites for dermal fat graft. Ann Plast Surg 2001;46: 327-31.

13. Orgill DP, Ogawa R. Current methods of burn reconstruction. Plast Reconstr Surg 2013;131:827e-836e.

14. Kokkoli E, Shih HS, Spyropoulou GA, Jeng SF. Local free-style perforator flaps in head and neck reconstruction: an update and a useful classification. Plast Reconstr Surg 2016;137:1863-74.

15. Lee KT, Mun GH. A systematic review of functional donor-site morbidity after latissimus dorsi muscle transfer. Plast Reconstr Surg 2014;134:303-14.

16. Chen YC, Scaglioni MF, Carrillo Jimenez LE, Yang JC, Huang EY, Lin TS. Suprafascial anterolateral thigh flap harvest: a better way to minimize donor-site morbidity in head and neck reconstruction. Plast Reconstr Surg 2016;138:689-98.

17. Zhang YX, Hayakawa TJ, Levin LS, Hallock GG, Lazzeri D. The economy in autologous tissue transfer: part 1. the kiss flap technique. Plast Reconstr Surg 2016;137:1018-30. 